\title{
Detection of Cryptosporidium $s p$ infection by PCR and modified acid fast staining from potassium dichromate preserved stool
}

\author{
Agnes Kurniawan, ${ }^{1}$ Sri W. Dwintasari, ${ }^{1}$ Herbowo A. Soetomenggolo, ${ }^{2}$ Septelia I. Wanandi. ${ }^{3}$ \\ ${ }^{1}$ Department of Parasitology Faculty of Medicine University of Indonesia, Jakarta \\ ${ }^{2}$ Department of Padiatrics, FKUI-RSCM and RSIA Hermina, Jakarta \\ ${ }^{3}$ Department of Biochemistry and Molecular Biology Faculty of Medicine University of Indonesia, Jakarta
}

\begin{abstract}
Abstrak
Tujuan Untuk mengetahui frekuensi infeksi Cryptosporidium sp pada anak bawah tiga tahun (batita) dengan deteksi gen $18 S$ rRNA dari tinja yang sudah dipreservasi lama dan membandingkannya dengan modifikasi metode tahan asam (MTA) dari tinja hasil konsentrasi.
\end{abstract}

\begin{abstract}
Metode Sejumlah 188 feses anak batita yang telah tersimpan selama 13 bulan di $4^{\circ} \mathrm{C}$, dikonsentrasikan dengan teknik air eter, selanjutnya dibuat sediaan, dipulas dengan pewarnaan MTA; sisa konsentrat diekstraksi DNA dengan teknik kejut panas dingin dan penambahan proteinase K, lalu dilakukan PCR langsung terhadap gen $18 S$ rRNA.
\end{abstract}

Hasil Proporsi sampel positif Cryptosporidium adalah 34.6\% dengan PCR gen 18 s rRNA dan 4.8\% dengan pulasan MTA dari tinja konsentrasi. Secara statistik perbedaan kedua hasil tersebut bermakna.

Kesimpulan Frekuensi infeksi Cryptosporidium sp di batita tinggi sekali dan penyimpanan tinja dalam larutan kalium dikromat selama 13 bulan, tampaknya tidak mempengaruhi hasil PCR. Tingginya frekuensi infeksi Cryptosporidium di populasi itu menunjukkan tingginya transmisi di daerah tersebut sehingga berpotensi menular ke kelompok yang rentan misalnya imunokompromais. (Med J Indones 2009; 18: 149-54)

\begin{abstract}
Aim To identify the frequency of Cryptosporidium infection in children below 3 years old by examining concentrated long term preserved stool using PCR detection of $18 \mathrm{~S}$ rRNA gene and compared with modified acid fast staining technique.

Methods Hundred eighty eight stools from children $\leq 3$ years old were stored for 13 months in $2.5 \% \mathrm{~K} 2 \mathrm{Cr} 2 \mathrm{O} 7 \mathrm{solution}$ at $4^{0} \mathrm{C}$. Cryptosporidium oocysts were isolated by water-ether concentration technique. The concentrates were smeared onto object glass and stained with modified acid fast staining, and the rest of the concentrates were DNA extracted by freezing and thawing cycles and proteinase K digestion, then direct PCR was done to detect 18S rRNA gene.

Result The proportion of positive stools for Cryptosporidium sp by acid fast staining from concentrated stools and 18S rRNA PCR were $4.8 \%$ and $34.6 \%$ respectively, which showed statistically significant difference.

Conclusion The frequency of Cryptosporidium infection among children $\leq 3$ years old was very high and stool storage in $\mathrm{K} 2 \mathrm{Cr} 2 \mathrm{O} 7$ for 13 months did not affect the PCR result. High prevalence of Cryptosporidium infection indicated high transmission in that area and the potential to be transmitted to other individuals such as the immunocompromised. (Med J Indones 2009; 18: 149-54)
\end{abstract}

Key words: $18 S$ rRNA, cryptosporidiosis

DNA can be isolated from any biological specimens; the most often widely used specimen is blood and hair because they are easily available. The DNA will be used to identify an organism by PCR, which is a method firstly introduced by Mullis in 1985 . This method was developed further by the Department of Human Genetics, Cetus Corporation, California for the amplification of $\beta$-globin human gene to diagnose prenatal genetic disorder such as sickle cell anemia. ${ }^{1}$

The rRNA is present in ribosomes of all organisms, the pro and eucaryote, which consist of small and large subunits. The $18 \mathrm{~S}$ rRNA is present in the small ribosome subunit in the cytosol of eucaryotes. ${ }^{2}$ In medicine, rRNA is the target of antibiotics, while in evolution, rRNA can be used in the taxonomy of an organism, to calculate the distance of relationship between one organism to another, and to calculate species divergence. ${ }^{3}$ Identification of $18 \mathrm{~S}$ rRNA gene was used to study a number of eukaryotes such as plants, animals and protozoa as well as Cryptosporidium. ${ }^{4}$

Cryptosporidium $s p$. is an intestinal coccidian protozoa, which infects animal as well as human and causes 
diarrhoea in immunocompetent and immunocompromised; with severe clinical manifestation in immunocompromised. Cryptosporidium is transmitted through fecal contamination of food or drinking water. Animals that are most frequently infected by Cryptosporidium $s p$ are mammalian, poultry, reptile and fish. Distribution of Cryptosporidium varies considerably, depending on the geography and host's type. Cryptosporidium infection is cosmopolitant. Low economy status, poor sanitation and water treatment will result in high prevalence of infection and diarrhoea epidemic. Infection mostly happen in children less than two years old and immunocompromised individuals. ${ }^{4}$

Cryptosporidium prevalence varies in different groups/ population. Kurniawan et $\mathrm{al}^{5}$ reported that $11.9 \%$ of HIV patients $(n=318)$ with chronic diarrhoea in Jakarta were positive for Cryptosporidium sp oocysts, while in Medan General hospital only $2.9 \%$ of children with diarrhoea $(n=172)$ were postive. ${ }^{6}$ In West Africa the prevalence was $7.7 \%$ in children of less than 3 years old, ${ }^{7}$ whereas in Iran the prevalence was 25.6 and $3.7 \%$ in adults with and without diarrhoea respectively. ${ }^{8}$ All the data were obtained by performing modified acid fast staining (AFS), the most common method used in nearly every laboratory in developing countries. ${ }^{9}$

The use of AFS method is relatively time consuming and needs skilled technician due to the very small oocyst (size: $4-6 \mu \mathrm{m}),{ }^{4}$ which is sometimes difficult to differentiate from the fungal spores of the same size and stained red too. In order to solve the problem, better techniques with higher sensitivity and specificity is necessary such as the PCR.

DNA isolation from faecal specimen is not as simple as those from blood; this is due to the presence of inhibitors in stool that can interfere with the PCR reaction. Apart from that, target gene, type of preservative solution and duration of storage determine the success of the test.

During a field study, a lot of specimens were collected, which were not possible to be examined immediately. Therefore, they were stored in a preservative solution such as formaldehyde or potassium dichromate until the test was performed. Johnson et $\mathrm{al}^{10}$ recommended $2.5 \%$ potassium dichromate as the best preservative without affecting PCR result. Oocyst viability can stay up to 18 months without degradation of its quality.

There are several target genes for the diagnosis of Cryptosporidium sp. such as Cryptosporidium oocyst wall protein (COWP), ${ }^{11} 18 \mathrm{~S}$ rRNA and some other genomes; the $18 \mathrm{~s}$ rRNA gene is the most specific gene with the highest sensitivity and able to detect up to one oocyst. ${ }^{12}$

Cryptosporidiosis thus represents a global public health problem that affects mainly children and the immunocompromised, and reliable detection methods are needed in order to identify the real prevalence, source of infection and transmission. Soetomenggolo et $\mathrm{al}^{13}$ found a $2.1 \%$ prevalence of Cryptosporidium among children below 3 years old that lived in the flooded area at Ciliwung riverside in East Jakarta, based on the modified AFS method from unconcentrated stools. This prevalence is much lower than reports from other developing countries with similar situation, culture and geography. This study aimed to reveal the frequency of Cryptosporidium infection among children below 3 years old, who lived at Ciliwung riverside in East Jakarta by PCR detection of $18 \mathrm{~S}$ rRNA gene from long term preserved stool, and to compare the PCR method with modified AFS method on concentrated stools.

\section{METHODS}

This was a descriptive, cross sectional study. The number of samples (188) was determined by statictical calculation using two proportional sampling test. ${ }^{14}$ The study was carried out at the Department of Parasitology, Faculty of Medicine, University of Indonesia.

\section{Samples}

The 188 stools were randomly selected from 486 stools from previous study which were collected from children $\leq 3$ years old who lived at the Ciliwung riverside, and preserved in $2.5 \%$ potassium dichromate, ${ }^{13}$ and stored at $4^{\circ} \mathrm{C}$ for 13 months. We used the modified AFS method and PCR to detect cryptosporidiosis on concentrated stools. The stages that was performed to detect $18 \mathrm{~S}$ rRNA gene by PCR were stool concentration to isolate the oocysts, DNA extraction and PCR amplification.

\section{Stool concentration}

Water ether stool concentration was performed following the Smith method. ${ }^{12}$ About $200 \mu$ of stool was mixed with $700 \mu \mathrm{l}$ of water in a $1.5 \mathrm{ml}$ centrifuge tube, and vortexed for 30 seconds. Diethyl ether was added as much as $400 \mu \mathrm{l}$, shook and spinned for 60 seconds at $13,000 \mathrm{~g}$. The supernatant was discarded and $200 \mu \mathrm{l}$ sediment was left. The sediment was washed 3 times with water and last sediment left was $50 \mu \mathrm{l}$. Further 100 $\mu 1$ of lysis buffer was added, vortexed for 10 seconds, and the stool concentrate was processed for staining, or stored at $4^{\circ} \mathrm{C}$ for the next procedure. By this method, the oocysts in the stool were concentrated.

\section{Modified AFS}

Ten $\mu 1$ of the stool concentrate was smeared onto object glass, dried at room temperature and fixed with 
methanol for 3 minutes, then stained with 3\% carbol fuchsin for 15 minutes. After washing with water, the slide was dipped into acid methanol for 10 seconds, then washed and counter stained with $0.4 \%$ malachite green for 30 seconds, dried and read under light microscope at $400-1,000 \times$ magnification, to look for cryptosporidium oocyst.

\section{DNA extraction from stool concentrate ${ }^{15}$}

The rest of the stool concentrate was processed further for cryptosporidium oocyst DNA extraction by performing 15 cycles of freezing and thawing at one minute each in liquid nitrogen and $65^{\circ} \mathrm{C}$ waterbath. Particulate matter was removed by vortexing and centrifugation every five cycles. After this process, $2 \mu 1$ of $10 \%$ proteinase $\mathrm{K}$ solution was added and incubated for 3 hours at $55^{\circ} \mathrm{C}$ then transferred to $90^{\circ} \mathrm{C}$ for 20 minutes and cooled on ice for one minute. The samples were then centrifuged for 5 minutes at $13,000 \mathrm{x}$ g. Oocyst DNA containing supernatants were recovered and measured for DNA concentration and purity following Sambrook et al technique, ${ }^{1}$ then stored at $-20^{\circ} \mathrm{C}$ until it was used for PCR amplification. ${ }^{15}$

\section{PCR amplification and gel analysis of PCR products ${ }^{16}$}

Amplification of Cryptosporidium DNA was directed against 18S rRNA gene. Optimation of DNA template volume and the PCR reaction were done using positive control, Cryptosporidium DNA supplied by SPDL, UK and Cryptosporidium DNA isolated from HIV individuals positive for cryptosporidiosis. One $\mu \mathrm{l}$ of the oocyst DNA was used as amplification template in $25 \mu \mathrm{l}$ reaction mixture containing $10 \times$ Taq buffer, $2 \mathrm{mM}$ dNTP, $4 \mathrm{mg} /$ $\mathrm{ml} \mathrm{BSA,} \mathrm{20 \%} \mathrm{Tween-20,} \mathrm{25mM} \mathrm{MgCl}$, Taq polymerase (Qiagen), and 5'AAGCTCGTAGTTGGATTTCTG 3' and 5' TAAGGTGCTGAAGGAGTAAGG 3' primers.

Reaction mixtures were subjected to 39 cycles that consisted of 30 seconds denaturation at $94^{\circ} \mathrm{C}, 30$ seconds annealing at $55^{\circ} \mathrm{C}$, and then 4 seconds elongation at $72^{\circ} \mathrm{C}$. Each amplification run included a negative control (PCR water) and a positive control. The PCR products were analyzed on horizontal $1.2 \%$ agarose gels in TBE $0.5 \mathrm{x}$ buffer $\mathrm{pH}$ 8.0; positive result showed the 435 bp band.

\section{Statistical analysis}

Statistical analysis was performed using SPSS version 12.0 software (SPSS Inc., Chicago, IL, USA). Difference between the result obtained by PCR and modified AFS from concentrated stool was tested using Mc Nemar bivariate analysis. Statistical analysis differs significantly if the $P$ is $<0.05$.

\section{RESULTS}

\section{Stool concentration and modified AFS}

Modified AFS on 188 stool concentrates showed that nine samples $(4.8 \%)$ were positive for Cryptosporidium oocysts (table 1). The oocyst were round, $4-5 \mu \mathrm{m}$ in size and stained red with green background (Figure 1).

Table 1 : Proportion of Cryptosporidium positive samples by PCR and modified AFS from concentrated stools.

\begin{tabular}{lll}
\hline Methods & \multicolumn{2}{c}{ Total } \\
\cline { 2 - 3 }$(\mathrm{n}=188)$ & positive & negative \\
\hline PCR & $65(34.6 \%)$ & $123(65.4)$ \\
Modified AFS concentrated stool & $9(4.8 \%)$ & $179(95.2 \%)$
\end{tabular}

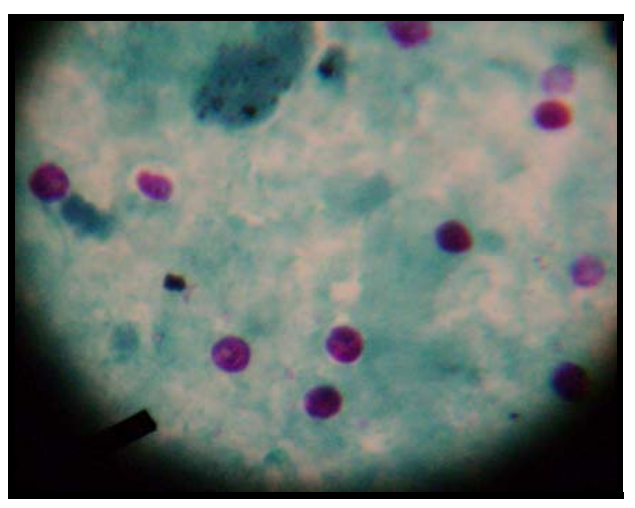

Figure 1. Cryptosporidium oocysts in stool concentrate, stained with modified acid fast staining (10 x 40)

\section{DNA extraction from stool concentrate}

The rest of concentrate was extracted for its oocyst DNA. Determination of DNA concentration by spectrophotometer showed high concentration of DNA isolated from the 188 stools. The average amount of isolated DNA was $83.288 \mu \mathrm{g}$ with average purity index of 1.09 .

\section{PCR Amplification of 18S rRNA Gene}

Optimation essay to determine the volume of template, which gave the best result showed that 1/10 dilution was the optimum volume of DNA template (Figure 2). From the 188 DNA samples that were analyzed by direct PCR against $18 \mathrm{~S}$ rRNA gene, 65 samples were positive $(34.6 \%)$, while the same samples that were examined by AFS showed only nine (4.8\%) positive for 
Cryptosporidium oocysts. Statistical analyses showed significant difference between the result obtained by PCR and microscopic examination by AFS from concentrated stools (Mc Nemar, $P=0.000$ ).

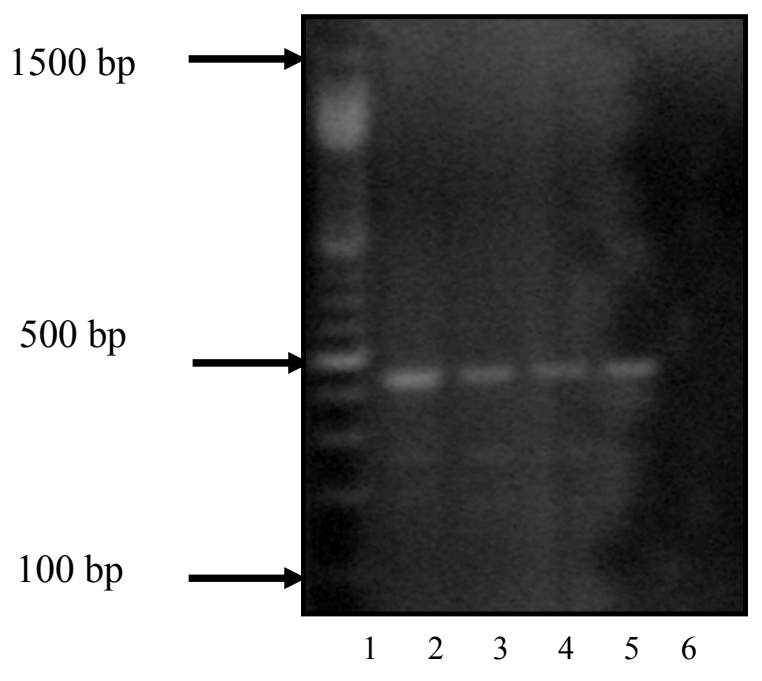

Figure 2. Results of PCR analysis on positive and negative control

Lane $1=100$ bp DNA marker (Promega)

Lane $2=1$ st positive control (Cryptosporidium DNA, SPDL, UK)

Lane $3=2$ nd positive control (1:9 dilution) (Cryptosporidium DNA, FKUI)

Lane $4=2$ nd positive control (1:5 dilution) (Cryptosporidium DNA, FKUI)

Lane $5=2$ nd positive control (1:1 dilution) (Cryptosporidium DNA, FKUI)

Lane $6=$ negative control

\section{DISCUSSIONS}

Cryptosporidium $s p$. oocysts can be detected in stool, sputum and biopsy tissue. It is commonly found in stool because the habitat is in the gastrointestinal tract; thus intestinal cryptosporidiosis is a common manifestation.

Johnson et al, ${ }^{10}$ reported that the duration of storage and type of preservative solution had an influence on the PCR result. Cryptosporidium DNA was still detected when the stool was stored in $2.5 \%$ potassium dichromate solution up to 6 months, in contrast to preservation in $10 \%$ formaldehyde. Formaldehyde will harden the oocysts, and make it difficult to be broken and to isolate the sporozoites DNA. The dichromate ion is stable in acid environment $(\mathrm{pH}=7)$ and can conserve the oocyst and its DNA. ${ }^{17}$ Chan-Gu et al, ${ }^{17}$ in his study reported that C. baileyi oocysts were still alive after 18 month storage in $2.5 \%$ potassium dichromate solution.

In this study, the samples had been stored for 13 months in $2.5 \%$ potassium dichromate solution. In positive samples, modified AFS of concentrated stool still showed a high number of oocysts upon clear background; a condition that made it easier to identify the oocysts and to differentiate them from fungal spores. The stools were concentrated in order to increase the sensitivity of the test, because concentration allowed more volume of stool to be examined.

The concentration technique in this study was the water-ether method, which is recommended as the best technique to recover the oocyst (46-75\%) in comparison to the other two techniques, the sucrose density (24-65\%) and zinc sulphate flotation technique (22-41\%). ${ }^{12}$

Cryptosporidium sp. DNA can be detected after going through three stages: stool concentration to isolate the oocyst, DNA extraction, and DNA amplification and analysis. At oocyst isolation stage, extra washing with demineralized water during concentration technique was necessary in order to remove the preservative solution., ${ }^{1,4}$

During DNA extraction, firstly the oocysts were broken to release the sporozoites. This was done by performing heat and cold shock method, through heating at $65^{\circ} \mathrm{C}$ and chilling in liquid nitrogen. The isolated DNA was then measured for its purity by comparing the absorbance of DNA and protein. It was found that the average purity index in this study was 1.09 that suggested low purity; however, the DNA was still able to be detected. Sambrook et al, ${ }^{1}$ mentioned that it is not necessary to purify the DNA that is used as a template for PCR, because the primers were very specific.

The average concentration of isolated DNA in this study was $83.288 \mu \mathrm{g}$; this fact revealed that there was enough template for PCR, which basically needs $0.1-1 \mu \mathrm{g}$ per reaction. ${ }^{1}$

Apart from the factors mentioned above, the primers, polymerase and the presence of any inhibitor may have an influence on the PCR result. Stool contains more inhibitors such as bilirubin, bile salt and polysaccharide compared to other specimen or environment. Those inhibitors may interfere with the polymerase; thus to neutralize the inhibitors, bovine serum albumin (BSA) $4 \mathrm{mg} / \mathrm{ml}^{18}$ was added. The reaction misture should be mixed well with the DNA template to avoid the formation of sodium dodecyl sulphate (SDS) crystal in the lysis buffer, which may interfere the action of polymerase. There was also addition of $20 \%$ Tween20 solution to neutralize the SDS. ${ }^{1,12}$ The method and reaction mixture to isolate the DNA from stool needs special precaution to minimize the effect of inhibitors that are present in stool. The PCR is a very sensitive and 
specific detection technique, which resulted in much higher proportion of Cryptosporidium positive samples in comparison to the standard technique, which is used in the health laboratories, the acid fast staining.

This study showed that Cryptosporidium DNA could still be detected in stool that was preserved in $2.5 \% \mathrm{~K}_{2} \mathrm{Cr}_{2} \mathrm{O}_{7}$ for 13 months, and also in negative samples (no oocyst found) by modified AFS. Our result suggests $\mathrm{K}_{2} \mathrm{Cr}_{2} \mathrm{O}_{7}$ that is a good preservative for Cryptosporidium. The negative results by modified AFS could be due to either very few oocysts that were present in the stools, or there was no excreted oocyst at all. Negative result by modified AFS does not exclude any Cryptosporidium infection, because AFS cannot detect the thin wall oocysts, which are not excreted in the stool, but continue to infect other enterocytes in the host intestines (autoinfection).

Further, the actual prevalence of Cryptosporidium infection among children below 3 years old is high (34.6\%, $\mathrm{n}=188)$, but most are silent infection, without obvious clinical manifestation, the diarrhoea. ${ }^{13}$ Therfore, they can be regarded as carriers with a possibility to spread the infection through improper personal hygiene or bad sanitation to other individuals, in particular the immunocompromised such as those with HIV infection. Finally, the amount of Cryptosporidium DNA that was isolated from the preserved stool was more than enough to give a positive result, even using a direct method.

The use of PCR to detect Cryptosporidium infection will be very useful when dealing with a lot of specimens (such as in a survey) or in cases where oocysts are very few, or for environmental samples such as surface and river water, while the AFS that is less sensitive is better used for public service in hospitals and health laboratories, where the number of specimens are few. Sensitivity can be increased by stool concentration and repeated slide examination before a negative result is stated. ${ }^{19}$

The high proportion of Cryptosporidium infection in the area and its severe manifestation in immunocompromised individuals necessitate a further study to reveal the transmission route and species of Cryptosporidium.

In conclusion, the frequency of Cryptosporidium infection among children $\leq 3$ years old was very high and stool storage in $\mathrm{K}_{2} \mathrm{Cr}_{2} \mathrm{O}_{7}$ for 13 months did not affect the PCR result. High prevalence of Cryptosporidium infection indicated high transmission in that area and the potential to be transmitted to other individuals such as the immunocompromised.

\section{Acknowledgements}

The authors thank Prof. Huw Smith and Dr. R. Nichols from Scottish Parasite Diagnostic Laboratory (SPDL), Glasgow, UK, for providing quality assurance. This work is supported by the British Council through DelPHE 73 project.

\section{REFERENCES}

1. Sambrook J, Fritsch EF, Maniatis T. Molecular cloning laboratory manual. 3th ed. New York: Cold Spring Harbor Laboratory Press; 2001.

2. Glitz D. Protein synthesis: translation and posttranslation modification. In: Devlin TM, editor. Textbook of biochemistry with clinical correlations. 5th ed. New York: Wiley-Lis; 2002. p. 243.

3. Xia X, Xie Z, Kjer KM. 18S ribosomal RNA and tetrapod phylogeny. Syst Biol. 2003;52(3):283-95.

4. Smith HV, Nichols RAB. Cryptosporidium. In: Shabbir S, editor. Foodborne Diseases. New Jersey: Humana Press; 2007. p. 233-76.

5. Kurniawan A, Karyadi T, Dwintasari SW, Sari IP, Yunihastuti E, Djauzi S, et al. Intestinal parasitic infections in HIV/AIDS patients presenting with diarrhoea in Jakarta, Indonesia. Trans Roy Soc Trop Med Hyg. 2009. in press. doi:10.1016/j.trstmh.2009.02.017

6. Ghani L. Faktor-faktor risiko diare persisten pada anak balita. J Kedokter Trisakti. 2001;20(3).110-6.

7. Perch M, Sodemann M, Jakobsen MS, Valentiner-Branth P, Steinsland H, Fischer TK, et al. Seven years experience with Cryptosporidium parvum in Guinea-Bissau, West Africa. Ann Trop Paediatr. 2001;21:313-8.

8. Mirzaei M. Prevalence of Cryptosporidium sp. infection in diarrheic and non-diarrheic humans in Iran. Korean J Parasitol. 2007;45(2):33-7.

9. Veterinary and public health test standardization group on behalf of SGDIA. UK National Reference Method. Cryptosporidium: detection and identification in faeces. Standard Operating Procedure-for the examination of faeces for Cryptosporidium. 2006. NRM002. Available from: http://www. defra. gov. uk/animalh/diseases/vetsurvellance/ pdf/nrm-002 crypto. pdf. Accessed 20 November 2008.

10. Johnson DW, Pieniazek NJ, Griffin DW, Misener L, Rose JB. Development of a PCR protocol for sensitive detection of Cryptosporidium in water samples. Appl Environ Microbiol. 1995;61:3849-55.

11. Pedraza-Díaz S, Amar C, Nichols GL, McLauchlin J. Nested polymerase chain reaction for amplification of the Cryptosporidium oocyst wall protein gene. Emerg Infect Dis. 2001; 7(1): 49-56.

12. Smith HV. Diagnosis of human and livestock cryptosporidiosis. In: Fayer R, Xiao L, editors. Cryptosporidium and cryptosporidiosis. 2nd ed. London: CRC press; 2007 p.173- 203 
13. Soetomenggolo HA, Firmansyah A, Kurniawan A, Pujiastuti P. Cryptosporidiosis pada anak usia dibawah tiga tahun di daerah bantaran sungai Ciliwung kelurahan Kampung Melayu. Paediatr Indones. 2008;48(2):99-102.

14. Sastroasmoro S, Sofyan I. Dasar-dasar metodologi penelitian Klinis. 2nd ed. Jakarta:Sagung Seto; 2002.

15. Nichols RAB, Smith HV. Optimisation of DNA extraction and molecular detection of Cryptosporidium parvum oocysts in natural mineral water sources. J Food Prot. 2004;67:524-32.

16. Nichols RAB, Campbell B, Smith HV. Identification of Cryptosporidium spp oocysts in UK noncarbonated natural mineral waters and drinking waters using a modified nested PCR-RFLP assay. Appl Environ Microbiol. 2003;69:4183-9.

17. Surl Chan-Gu, Kim Se-Min, Kim Hyeon-Cheol. Viability of preserved Cryptosporidium baileyi oocysts. Korean J Parasitol. 2003;41(4):197-201.

18. Bessetti J. An introduction to PCR inhibitors. Promega. 2007. http://www.promega.com/profiles / 1001 / Profilesin DNA_1001_09. pdf. Accessed 28 November 2008.

19. WeberR,ByanRT,Juranek DD. Improved stoolconcentration procedure for detection of Cryptosporidium oocysts in fecal specimens. J Clin Microbiol. 1992;30(11):2869-73. 